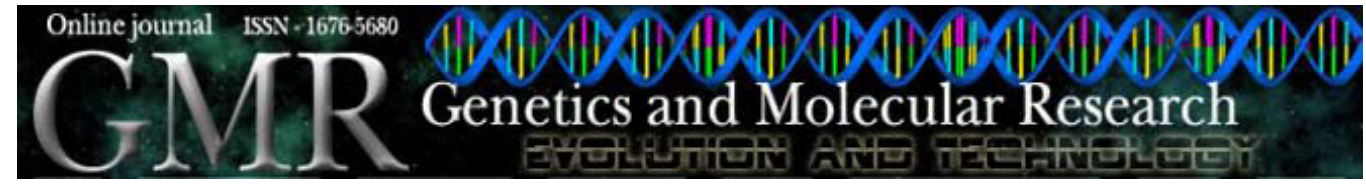

\title{
pelB gene in isolates of Colletotrichum gloeosporioides from several hosts
}

\author{
L.V. Medeiros ${ }^{1}$, D.B. Maciel $^{1}$, V.V. Medeiros ${ }^{1}$, L.M. Houllou Kido ${ }^{2}$ and \\ N.T. Oliveira ${ }^{3}$ \\ ${ }^{1}$ Laboratório de Genética Molecular de Fungos, \\ Universidade Federal de Pernambuco, Recife, PE, Brasil \\ ${ }^{2}$ Centro de Tecnologias Estratégicas do Nordeste, Cidade Universitária, \\ Recife, PE, Brasil \\ ${ }^{3}$ Laboratório de Fitopatologia, Universidade Federal de Pernambuco, \\ Recife, PE, Brasil \\ Corresponding author: L.V. Medeiros \\ E-mail: lilivmedeiros@yahoo.com.br
}

Genet. Mol. Res. 9 (2): 661-673 (2010)

Received December 18, 2009

Accepted January 22, 2010

Published April 13, 2010

DOI 10.4238/vol9-2gmr725

\begin{abstract}
Colletotrichum gloeosporioides is an important pathogen for a great number of economically important crops. During the necrotrophic phase of infection by Colletotrichum spp, the degradative enzymes of plant cell walls, such as pectate lyase, clearly increase. A gene pelB that expresses a pectate lyase was identified in isolates of $C$. gloeosporioides in avocado pathogens. Various molecular studies have identified a kind of specialization of C. gloeosporioides isolates with specific hosts; however, there have been no studies of this gene in isolates from hosts other than avocado. The same is true for other species of Colletotrichum. We examined genetic variability in order to design primers that would amplify pelB gene fragments and compared the products of this amplification in C. gloeosporioides isolates from different hosts. Genetic variability was assessed using ISSR primers; the resultant data were grouped based on the UPGMA clustering method. Primers for the pelB gene were designed from selected GenBank sequences using the Primer 3 program at an annealing temperature of $60^{\circ} \mathrm{C}$
\end{abstract}


and product amplification of nearly $600 \mathrm{bp}$. The ISSR primers were efficient in demonstrating the genetic variability of the Colletotrichum isolates and in distinguishing C. gloeosporioides, C. acutatum and C. sublineolum species. The gene pelB was found in C. gloeosporioides, C. acutatum and C. sublineolum. Amplified restriction fragments using $M s p \mathrm{I}$ did not reveal differences in $p e l \mathrm{~B}$ gene structure in isolates from the three different host species that we investigated.

Key words: Colletotrichum; CgInt; ISSR; pelB gene; Pectate lyase

\section{INTRODUCTION}

Fungi of the genus Colletotrichum and its teleomorph Glomerella are among the main pathogens studied and are responsible for huge losses in many tropical, subtropical and temperate crops. Cereal, vegetable, ornamental, and fruit crops can be seriously affected by fungus, leading to significant reductions in production. In the case of fruit crops, even though the fungus infects different aerial parts of the plant, the most significant economic losses stem from the attack on the fruits. In addition, infection can occur and remain quiescent until post-harvest, when the typical symptoms develop, extending losses to merchants and consumers (Bailey and Jeger, 1992; Freeman et al., 1998, 2000). Due to the high genetic plasticity and the great dependence on environmental factors, pathogenic agents are subject to constant physio- and morphological changes in pathogenic behavior (Michereff, 2000). With the existence of species-specific primers based on nucleotide sequences of internal transcribed spacer region 1 (ITS1) of rDNA, polymerase chain reaction (PCR) has become a powerful tool to aid in the identification of Colletotrichum species (Brown et al., 1996). Other techniques such as the analysis of the inter-simple sequence repeats (ISSR) region, oligonucleotides of microsatellites have been used to demonstrate the intraspecific genetic variability of fungi of agronomic interest (Vainio et al., 1998; Yu et al., 2006; Chadha and Gopalakrishna, 2007; Bayraktar et al., 2008).

Knowledge of the molecular basis of the action of plant pathogens including the structure and evolution of genes related to pathogenicity is of fundamental importance to disease control programs (Perfect et al., 1999).

The enzymes that degrade the cell wall and other physical barriers, such as cutin and pectin of plants, may be essential for pathogenicity (Lebeda et al., 2001). In the necrotrophic phase of infection by Colletotrichum species, enzymes that degrade the plant cell wall such as endopolygalacturonase and pectate lyase show clear increase in expression (Perfect et al., 1999). In the Glomerella cingulata teleomorph of C. gloeosporioides, efforts have been made to characterize these pectate lyases. Such a gene called pelB coding for a pectate lyase was identified in isolates of $C$. gloeosporioides and mutants with deletions of this gene showed reduced pathogenicity to avocado (Persea amarican Mill.) (Yacoby et al., 2001). So far, studies on the pel $\mathrm{B}$ gene, which encodes a pectate lyase, were performed on isolates of $C$. gloeosporioides from avocado but were not extended to other isolates of the same species from other hosts, thus requiring knowledge of its distribution and variations in sequence. The objectives of this study were to assess genetic variation and the presence of the pathogenic $p e l \mathrm{~B}$ gene and to compare the amplification products of this gene in isolates from different hosts of $C$. gloeosporioides. 


\section{MATERIAL AND METHODS}

\section{Colletotrichum isolates}

Twenty isolates of Colletotrichum from different hosts attacked by anthracnose were used. They were provided by the Culture Collection - URM (University of Recife - Mycology) of the Mycology Department, Federal University of Pernambuco and the Pathology Sector of the Luis de Queiroz School of Agriculture (ESALQ-USP) (Table 1). Isolates of C. acutatum and C. sublineolum were used for comparative analysis of genetic variability and structure of the pelB gene.

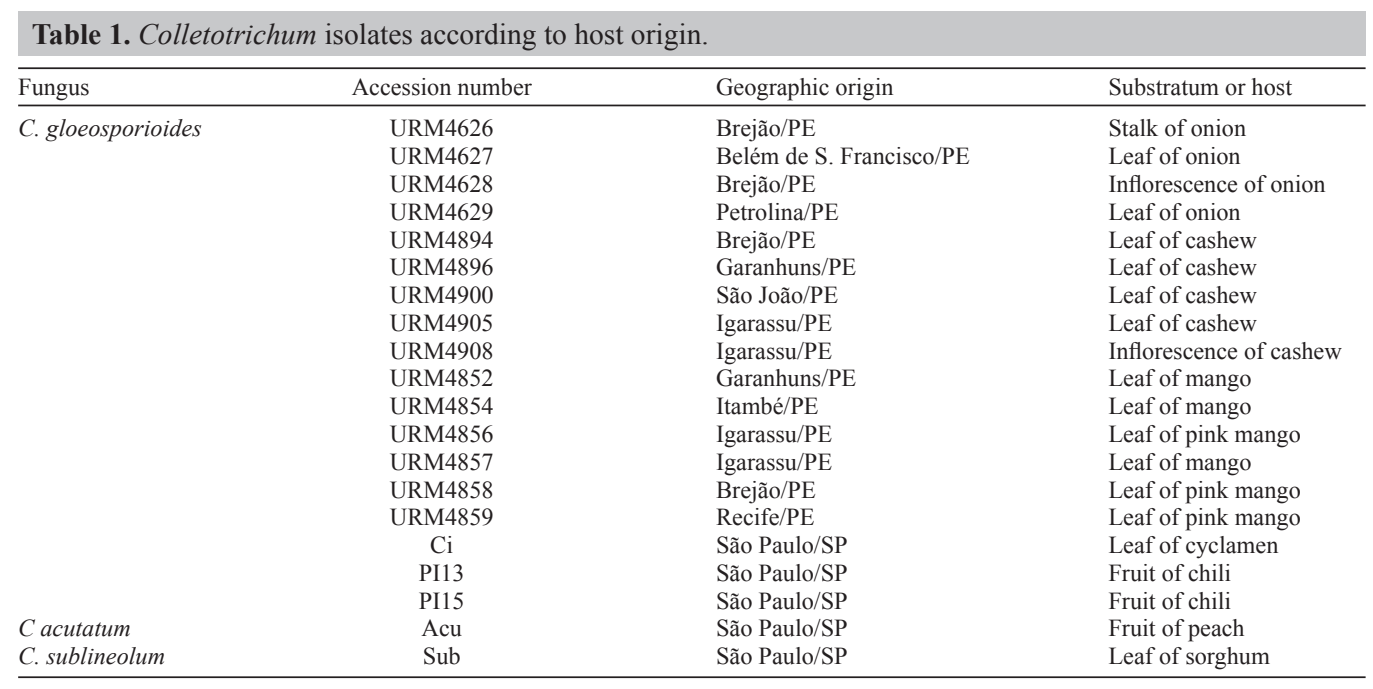

$\mathrm{PE}=$ Pernambuco; $\mathrm{SP}=$ São Paulo

\section{Obtaining the mycelium and DNA extraction}

Conidia of each isolate were suspended in $3 \mathrm{~mL} 0.1 \%$ Tween $20(\mathrm{v} / \mathrm{v})\left(10^{6}\right.$ conidia/ $\mathrm{mL}$ ) and transferred to Erlenmeyer flasks containing $100 \mathrm{~mL}$ liquid minimal medium. Vials were shaken at $27 \mathrm{rpm}$ for $120 \mathrm{~h}$ at $28^{\circ} \mathrm{C}$ for fungal growth. Subsequently, the mycelium was collected by vacuum filtration and washed with autoclaved distilled water. The wet weight was determined and the sample stored at $-20^{\circ} \mathrm{C}$ until use for DNA extraction. DNA was extracted following the technique described by Kuramae-Izioka (1997). The mycelial mass was ground with liquid nitrogen and transferred to microtubes, to which $700 \mu \mathrm{L}$ extraction buffer $(1 \mathrm{M}$ Tris- $\mathrm{HCl}, \mathrm{pH} 8.0,250 \mathrm{mM} \mathrm{NaCl}, 0.5 \mathrm{mM}$ EDTA, $\mathrm{pH}$ 8.0, 10\% sodium dodecyl sulfate) was added. After homogenization, the microtubes were incubated at $65^{\circ} \mathrm{C}$ for $30 \mathrm{~min}$ and gently shaken by inversion every $10 \mathrm{~min}$, after which $500 \mu \mathrm{L} 5 \mathrm{M}$ potassium acetate was added, followed by homogenization and centrifugation at $14,500 \mathrm{~g}$ for $10 \mathrm{~min}$. The supernatant was extracted with 1 volume of chloroform-isoamyl alcohol (24:1), and subsequently, centrifugation was carried out at $14,500 \mathrm{~g}$ for $10 \mathrm{~min}$. One volume of isopropanol was added to the recovered aqueous phase, and the mixture cooled to $4^{\circ} \mathrm{C}$ for DNA precipitation. Samples were again subjected to centrifugation at $14,500 \mathrm{~g}$ for $10 \mathrm{~min}$. The precipitate was washed with $70 \%$ 
ethanol, centrifuged for $10 \mathrm{~min}$, dried at room temperature, resuspended in TE buffer, $\mathrm{pH} 8.0$ (1 M Tris- $\mathrm{HCl}, 0.5 \mathrm{M}$ EDTA) and stored in a refrigerator at $-20^{\circ} \mathrm{C}$.

The DNA concentration was estimated by electrophoresis on a $0.8 \%$ agarose gel at $3 \mathrm{~V} / \mathrm{cm}$ distance between the electrodes with $1 \mathrm{X}$ Tris-borate-EDTA (TBE) running buffer in comparison with the lambda phage DNA molecular weight marker (Invitrogen Life Technologies). After electrophoresis, the gel was stained in ethidium bromide solution (1X TBE/ $0.5 \mu \mathrm{g} /$ $\mathrm{mL}$ EtBr; Sambrook et al., 1989) for 30 min, observed with an ultraviolet transilluminator and photographed using a Sony digital camera (effective 7.2 megapixels).

\section{Amplification with primers CgInt/ITS4}

For specific confirmation of Colletotrichum isolates, we used the species-specific primer CgInt (5'-GGCCTCCCGCCTCCGGGCGG-3') in combination with the universal primer ITS4 (5'-TCCTCCGCTTATTGATATGC-3'), according to Freeman et al. (2000). The amplification reactions were performed in a final volume of $25 \mu \mathrm{L}$ containing: buffer $(20 \mathrm{mM}$ Tris-HCl, $\mathrm{pH} 8.4,50 \mathrm{mM} \mathrm{KCl}), 1.5 \mathrm{mM} \mathrm{MgCl}, 0.2 \mathrm{mM}$ dNTP, $0.5 \mathrm{mM}$ primer, $0.04 \mathrm{U}$ Taq DNA polymerase (Invitrogen Life Technologies) and $25 \mathrm{ng}$ DNA. The thermal cycler Techne TC-512 was used with the following schedule: initial denaturation at $95^{\circ} \mathrm{C}$ for $5 \mathrm{~min}, 40$ cycles at $95^{\circ} \mathrm{C}$ for $30 \mathrm{~s}, 50^{\circ} \mathrm{C}$ for $30 \mathrm{~s}$ and $72^{\circ} \mathrm{C}$ for $1 \mathrm{~min}$ and $30 \mathrm{~s}$. Amplified products were separated by electrophoresis on a $1 \%$ agarose gel at $3 \mathrm{~V} / \mathrm{cm}$ in $0.5 \mathrm{X}$ TBE running buffer, $\mathrm{pH} 8.0$, using a 100-bp molecular weight marker (Invitrogen Life Technologies). After electrophoretic migration, the gel was stained in ethidium bromide solution for $30 \mathrm{~min}$, visualized with an ultraviolet transilluminator and photographed with a Sony digital camera (effective 7.2 megapixels).

\section{ISSR by PCR}

DNA samples were subjected to PCR with primers $(\mathrm{GTG})_{5},(\mathrm{GACA})_{4}$ and M13. The amplification reactions were performed in a final volume of $25 \mu \mathrm{L}$ under the following conditions: buffer (20 mM Tris- $\mathrm{HCl}$, pH 8.4, $50 \mathrm{mM} \mathrm{KCl}$ ), $0.75 \mathrm{mM} \mathrm{MgCl}_{2}, 0.25 \mathrm{mM}$ dNTP, $0.25 \mathrm{mM}$ primer, 0.1 U Taq DNA polymerase (Operon Technologies) and $25 \mathrm{ng}$ DNA, as described by de Barros Lopes et al. (1996). The amplification cycles consisted of an initial denaturation step at $95^{\circ} \mathrm{C}$ for $5 \mathrm{~min}$ followed by 40 cycles of $20 \mathrm{~s}$ at $95^{\circ} \mathrm{C}, 45 \mathrm{~s}$ at $55^{\circ} \mathrm{C}$ and $1 \mathrm{~min}$ at $72^{\circ} \mathrm{C}$, followed by a final extension of $3 \mathrm{~min}$ at $72^{\circ} \mathrm{C}$. Amplified products were separated by electrophoresis on a $1.4 \%$ agarose gel at 3 $\mathrm{V} / \mathrm{cm}$ in $1 \mathrm{X}$ TBE running buffer, $\mathrm{pH}$ 8.0, using a 100-bp molecular weight marker (Invitrogen Life Technologies). Subsequently, the gel was stained in ethidium bromide solution for $30 \mathrm{~min}$, visualized with an ultraviolet transilluminator and photographed with a Sony digital camera (effective 7.2 megapixels). The data obtained from the amplification with the microsatellite markers were analyzed with the Numerical Taxonomy System of Multivariate Programs - NTSYS-PC (Bussab et al., 1990; Rohlf, 2002), using the Jaccard coefficient. The dendrogram was generated by the clustering method UPGMA (unweighted pair group method with arithmetic average).

\section{Design of specific primers for the pelB gene and optimization of PCR}

Primers for PCR were designed from sequences of C. gloeosporioides selected from GenBank (National Center for Biotechnology Information, http://www.ncbi. 
nlm.nih.gov) using the Primer 3 program (Rozen and Skaletsky, 2000). The primers were named P1 (5'-ACGAAAACCACCAACCACA-3') with $\mathrm{Tm}$ of $53.1^{\circ} \mathrm{C}$ and $\mathrm{P} 6$ (5'-TGGAGGCGTGAGTGATGTC-3') with Tm of $53.7^{\circ} \mathrm{C}$, and the amplification products had an expected size of approximately $600 \mathrm{bp}$. The PCR conditions were optimized in thermal cycler with a temperature gradient. The optimization reaction showed that $60^{\circ} \mathrm{C}$ was the optimal annealing temperature for the pair of primers designed. The amplification reactions were performed in a final volume of $25 \mu \mathrm{L}$ under the following conditions: $1 \mathrm{X}$ buffer $(20 \mathrm{mM}$ Tris- $\mathrm{HCl}, \mathrm{pH} 8.4,50$ $\mathrm{mM} \mathrm{KCl}), 1.5 \mathrm{mM} \mathrm{MgCl}, 0.3 \mathrm{mM}$ dNTP, $0.2 \mathrm{mM}$ of each primer, $0.04 \mathrm{U}$ Taq DNA polymerase (Invitrogen Life Technologies) and $25 \mathrm{ng}$ DNA. PCR involved an initial denaturation at $95^{\circ} \mathrm{C}$ for $5 \mathrm{~min}$, followed by 40 cycles at $95^{\circ} \mathrm{C}$ for $30 \mathrm{~s}$, annealing at $60^{\circ} \mathrm{C}$ for $30 \mathrm{~s}$, and extension at $72^{\circ} \mathrm{C}$ for $30 \mathrm{~s}$. The amplification products of the pelB gene were separated by electrophoresis on a $1 \%$ agarose gel at $3 \mathrm{~V} / \mathrm{cm}$ in $0.5 \mathrm{X}$ TBE running buffer, $\mathrm{pH} 8.0$, using a 100-bp molecular weight marker (Invitrogen Life Technologies). The gel was stained in ethidium bromide solution for 30 min, visualized with an ultraviolet transilluminator and photographed with a Sony digital camera (effective 7.2 megapixels).

\section{Enzymatic digestion of PCR products of the pelB gene}

The enzymatic digestion was performed by mixing $6 \mu \mathrm{L}$ amplification products of pelB with $20 \mu \mathrm{L}$ restriction mix containing $0.1 \mathrm{U}$ restriction enzyme MspI (Invitrogen Life Technologies) in buffer for specific restriction. After incubation for $1 \mathrm{~h}$ at $37^{\circ} \mathrm{C}$ with the enzyme, the resulting fragments were separated by electrophoresis on a $1.5 \%$ agarose gel at $3 \mathrm{~V} /$ $\mathrm{cm}$ distance between electrodes in 0.5X TBE running buffer, $\mathrm{pH} 8.0$, using a 100-bp molecular weight marker (Invitrogen Life Technologies). The restriction fragments were stained as described above.

\section{RESULTS}

\section{Specific characterization with primers CgInt/ITS4}

The amplification using primers CgInt/ITS4 (Figure 1) was positive for all isolates of $C$. gloeosporioides, generating fragments of approximately $450 \mathrm{bp}$ and negative for isolates of $C$. acutatum and $C$. sublineolum. The use of species-specific primers confirmed the identity of isolates of $C$. gloeosporioides stored in the RMU fungal collection identified by classical methodology.

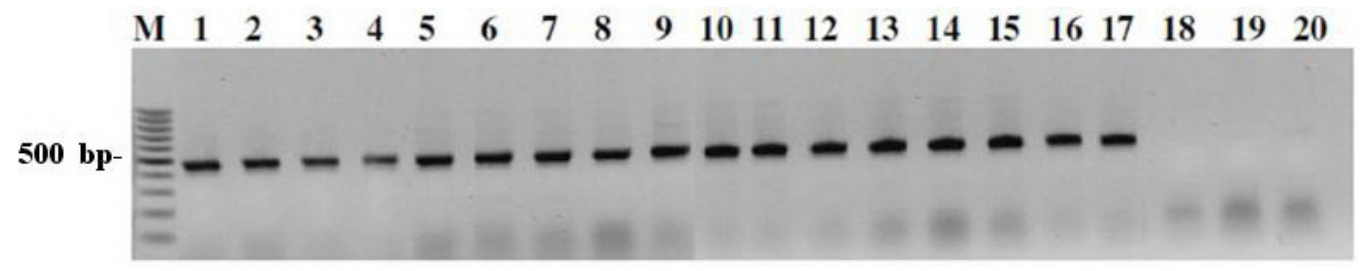

Figure 1. Profiles of amplification of specific fragments of 20 Colletotrichum gloeosporioides isolates with the primer CgInt/ITS4. $\mathrm{M}=$ Molecular weight size markers, $100 \mathrm{bp}$. Lanes 1-20= corresponding to strains URM4626, 4627, 4628, 4629, 4894, 4896, 4900, 4905, 4908, 4852, 4854, 4856, 4857, 4858, 4859, Ci, PI13, PI15, Acu, and Sub, respectively. 


\section{Analysis of ISSR regions}

The amplification profiles of the ISSR region, using the primers $(\mathrm{GTG})_{5},(\mathrm{GACA})_{4}$ and M13 are illustrated in Figure 2A, B and C, respectively. The dendrogram generated from the amplification profiles with the primer (GTG) ${ }_{5}$ (Figure 3) showed four groups at the similarity level of fragment size of $85 \%$. The first group is represented by four isolates of $C$. gloeosporioides: 4626 (onion peduncle/PE, which means Pernambuco), 4627 (onion leaf/PE), 4628 (onion inflorescence/PE), and 4629 (onion leaf/PE). The second group is formed by the species C. gloeosporioides: 4854 (sword mango leaf/PE), 4856 (pink mango leaf/PE), 4857 (sword mango leaf/PE), 4859 (pink mango leaf/PE), and 4858 (pink mango leaf/PE ). The third group is made up of two representatives of $C$. gloeosporioides: 4894 (cashew leaf/PE) and 4896 (cashew leaf/PE), and the fourth is formed by the species C. acutatum PI15 (pepper/ SP, which means São Paulo) and Acu (peach/SP). Representatives of the first group had 100\% similarity in fragment size and $65 \%$ similarity with the isolate 4905 (cashew leaf/PE) of $C$. gloeosporioides. The isolates from the second and third groups showed $100 \%$ similarity in fragment size, while the representatives of the fourth group showed $100 \%$ similarity among themselves and $20 \%$ similarity with the isolate Sub (sorghum/SP) of C. sublineolum. Analyzing the dendrogram, the isolates 4905 (cashew leaf/PE), Ci (cyclamen/SP), 4908 (cashew inflorescence/PE), 4900 (cashew leaf/PE), PI13 (pepper/SP), 4852 (sword mango leaf/PE), and $\mathrm{Sub}$ (sorghum/SP) were not grouped with other isolates of the same species, although this marker differentiated C. gloeosporioides, C. acutatum and C. sublineolum.
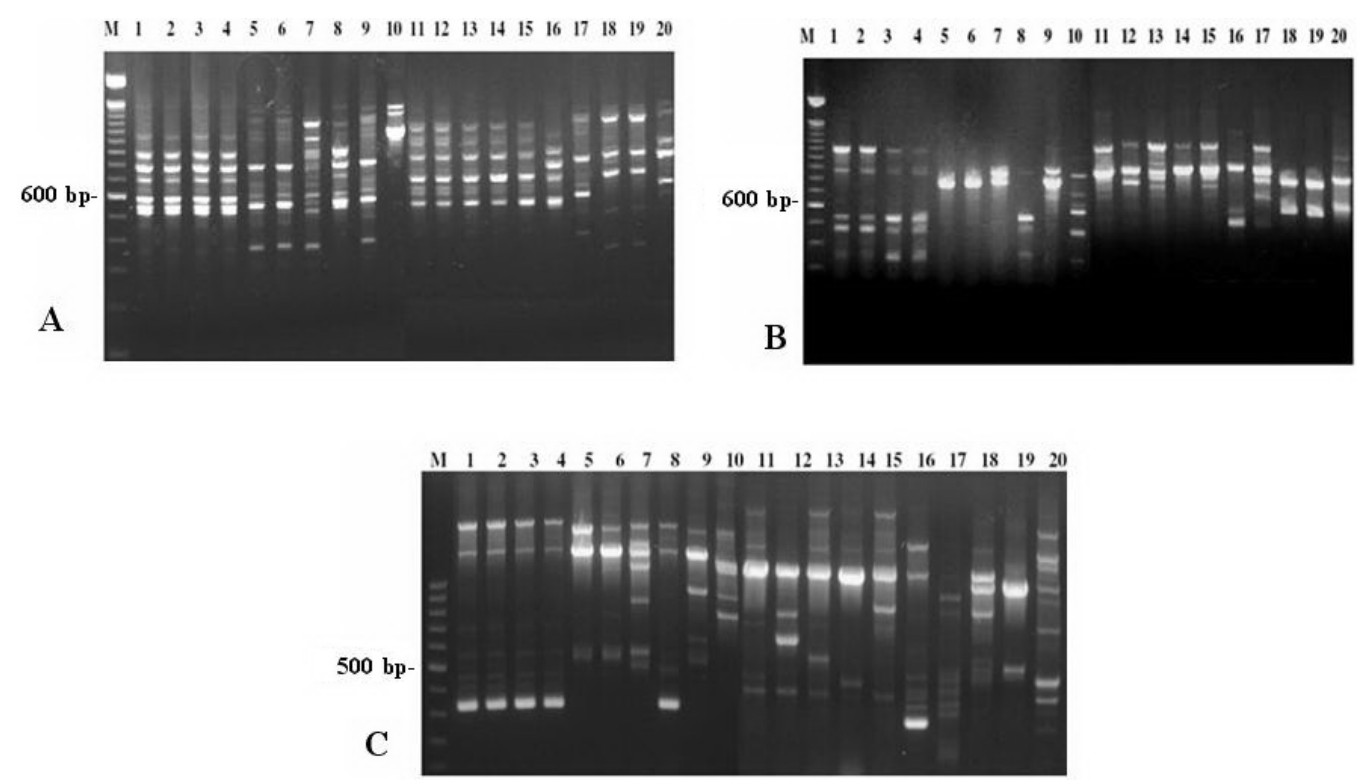

Figure 2. Amplification profiles of the ISSR regions with primers $(\mathrm{GTG})_{5}(\mathrm{~A}),(\mathrm{GACA})_{4}(\mathrm{~B})$ and $\mathrm{M} 13(\mathrm{C})$ of Colletotrichum isolates. Lane $M=1-\mathrm{kb}$ molecular weight marker (A and B) or $100 \mathrm{bp}(\mathrm{C})$. Lanes 1 to $17=\mathrm{DNA}$ of Colletotrichum gloeosporioides: 4626, 4627, 4628, 4629, 4894, 4896, 4900, 4905, 4908, 4852, 4854, 4856, 4857, 4858, 4859, Ci, and PI13. Lanes 18 and $19=$ DNA of C. acutatum (PI15 and Acu, respectively). Lane $20=$ DNA of C. sublineolum (Sub). 


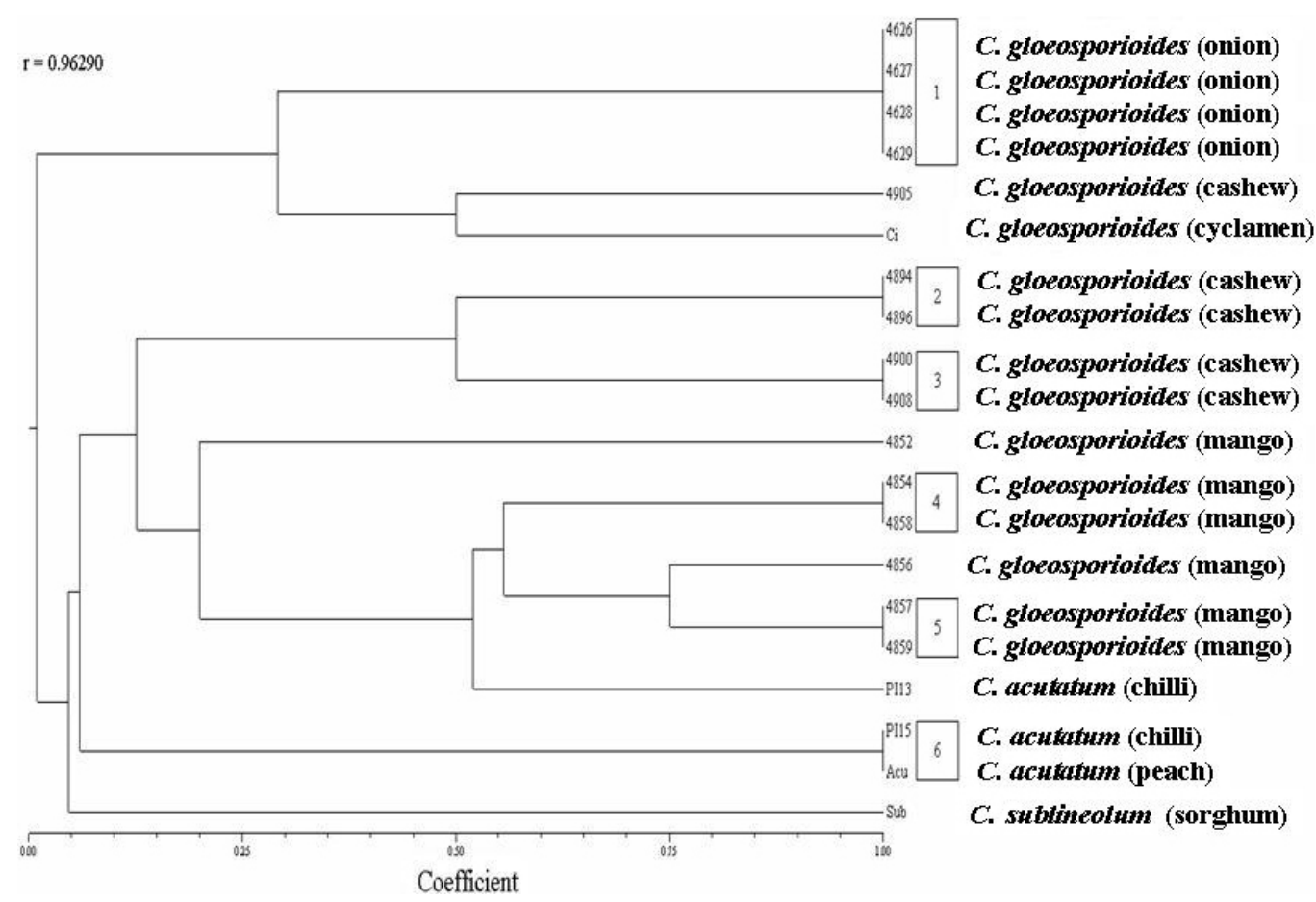

Figure 3. Dendrogram constructed by the UPGMA method, using the Jaccard coefficient ( $\mathrm{J}$ ) from the ISSR profiles with primer (GTG) ${ }_{5}$ obtained from 17 isolates of Colletotrichum gloeosporioides $(4626,4627,4628,4629,4894$, 4896, 4900, 4905, 4908, 4852, 4854, 4856, 4857, 4858, 4859, Ci, and PI13), 2 isolates of C. acutatum (PI15 and Acu), and 1 of C. sublineolum (Sub).

The amplification profiles of the ISSR regions, using the primer (GACA) $)_{4}$ are illustrated in Figure 4. The dendrogram (Figure 4) generated from the amplification profiles showed six groups, at the similarity level of fragment size of $85 \%$. The first group is represented by four isolates of C. gloeosporioides: 4626 (onion peduncle/PE), 4627 (onion leaf/PE), 4628 (onion inflorescence/PE), and 4629 (onion leaf/PE). The second group consisted of C. gloeosporioides isolates: 4894 (cashew leaf/PE) and 4896 (cashew leaf/PE). The third is represented by isolates of C. gloeosporioides: 4900 (cashew leaf/PE) and 4908 (cashew inflorescence/PE). The fourth group is formed by representatives of $C$. gloeosporioides: 4854 (sword mango leaf/PE) and 4858 (pink mango leaf/PE). The fifth is represented by isolates of $C$. gloeosporioides: 4856 (pink mango leaf/PE), 4859 (pink mango leaf/PE) and 4857 (sword mango leaf/PE). The sixth group consists of the representatives PI15 (pepper/SP) and Acu (peach/SP) of C. acutatum. The first group showed $100 \%$ similarity in fragment size and around 34\% similarity with the isolate 4905 of $C$. gloeosporioides, while the isolates from the other groups also showed $100 \%$ similarity in fragment size, and the isolate PI13 (pepper/SP) of C. gloeosporioides showed $45 \%$ similarity with the representatives of the fourth and fifth groups. Analyzing the dendrogram, the isolates 4905 (cashew leaf/PE), 4852 (sword mango leaf/PE), PI13 (pepper/SP), Ci (cyclamen/ $\mathrm{SP}$ ), and Sub (sorghum/SP) were distant from the other isolates of $C$. gloeosporioides, although this marker differentiated the three species studied. 


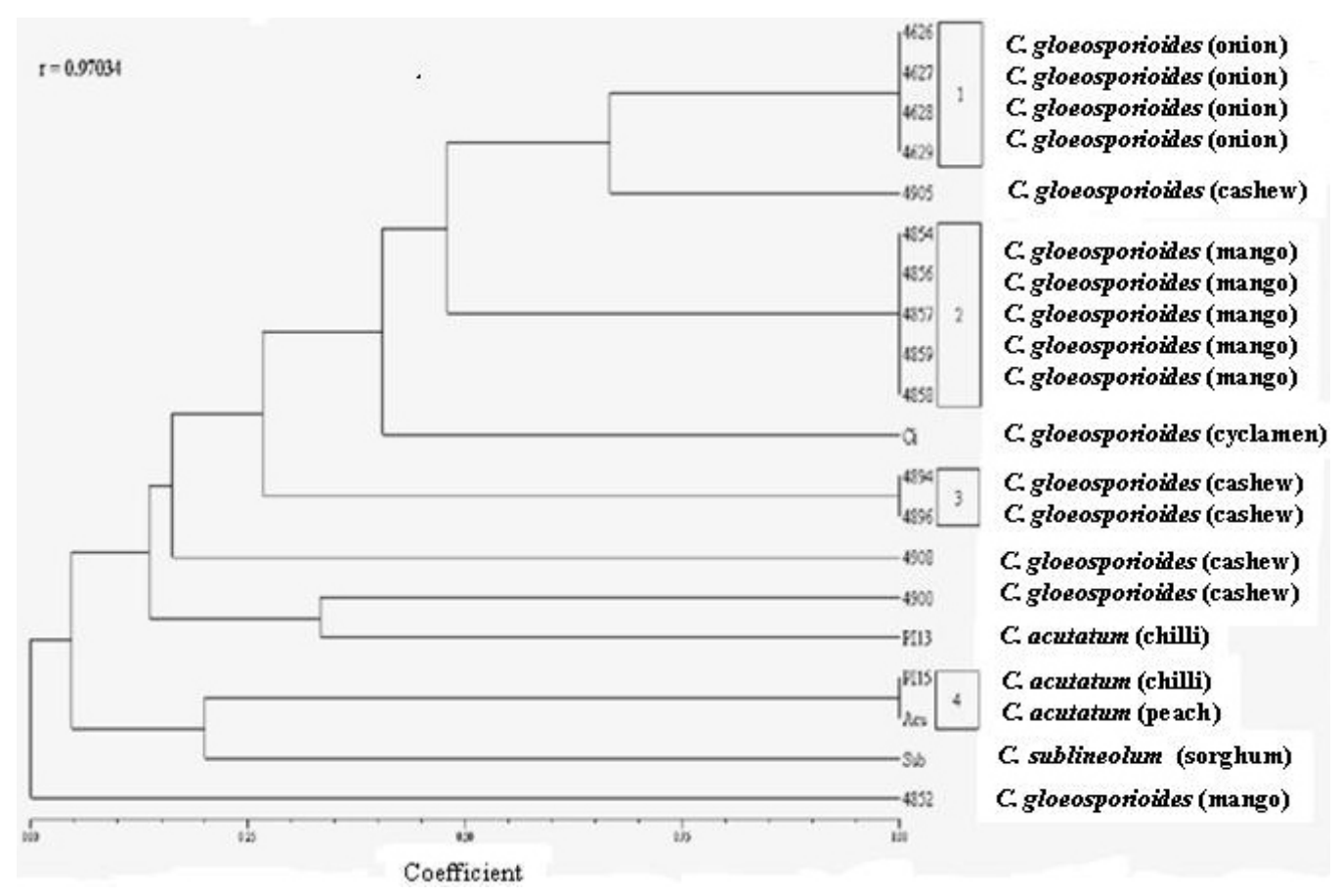

Figure 4. Dendrogram constructed by the UPGMA method, using the Jaccard coefficient (J) from the ISSR profiles with primer (GACA) obtained from 17 isolates of Colletotrichum gloeosporioides $(4626,4627,4628,4629,4894$, 4896, 4900, 4905, 4908, 4852, 4854, 4856, 4857, 4858, 4859, Ci, and PI13), 2 isolates of C. acutatum (PI15 and $\mathrm{Acu})$, and 1 of C. sublineolum (Sub).

The amplification profiles of the ISSR regions, using the primer M13 in 20 isolates of the genus Colletotrichum are illustrated in Figure 5. The dendrogram (Figure 5) generated from the amplification profiles showed three groups, at the level of similarity of fragment size of $85 \%$. The first group is represented by four isolates of C. gloeosporioides: 4626 (onion peduncle/PE), 4627 (onion leaf/PE), 4628 (onion inflorescence/PE) and 4629 (onion leaf/PE). The second group is formed of C. gloeosporioides isolates: 4894 (cashew leaf/PE), 4896 (cashew leaf/PE) and 4905 (cashew leaf/PE). The third group is represented by isolates of C. gloeosporioides: 4854 (sword mango leaf/PE) and 4857 (sword mango leaf/PE). The three groups showed 100\% similarity in fragment size; the isolate 4900 (cashew leaf/PE) of C. gloeosporioides showed $67 \%$ similarity to the representatives of the second group and the isolate 4859 (pink mango leaf/PE) showed 67\% similarity to the third group. Analyzing the dendrogram, the isolates 4900 (cashew leaf/ PE), 4908 (cashew inflorescence/PE), 4852 (sword mango leaf/PE), 4854 (sword mango leaf/PE), 4856 (pink mango leaf/PE), 4858 (pink mango leaf/PE), 4859 (pink mango leaf/ PE), PI13 (pepper/SP), PI15 (pepper/SP), and Ci (cyclamen/SP), Acu (peach/SP) and Sub (sorghum/SP) were distant from the other isolates of C. gloeosporioides, although this marker differentiated the three species studied. 


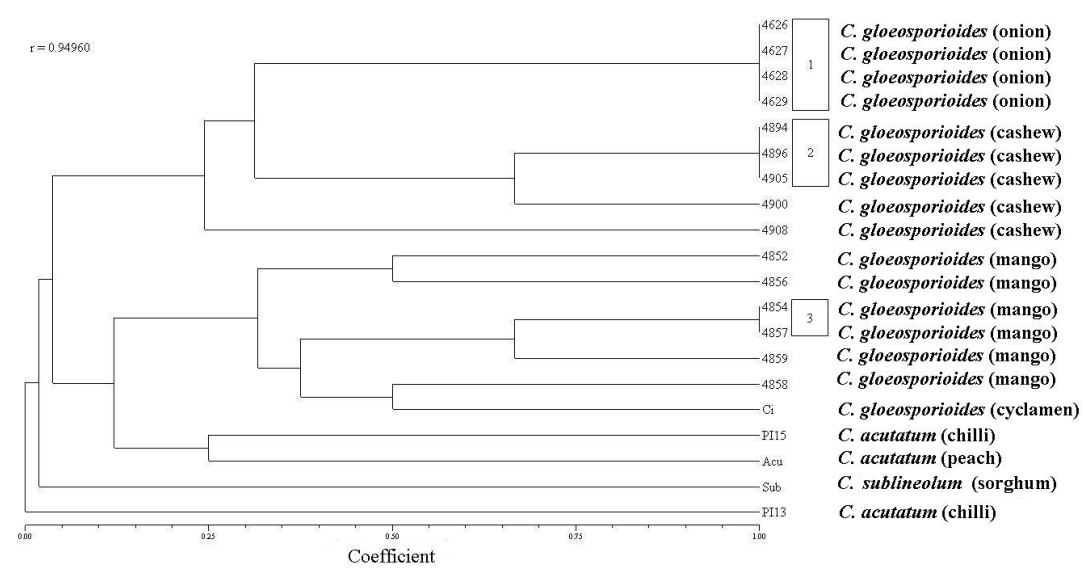

Figure 5. Dendrogram constructed by the UPGMA method, using the Jaccard coefficient (J) from ISSR profiles with primer M13 obtained from 17 isolates of Colletotrichum gloeosporioides (4626, 4627, 4628, 4629, 4894, 4896, 4900, 4905, 4908, 4852, 4854, 4856, 4857, 4858, 4859, Ci, and PI13), 2 isolates of C. acutatum (PI15 and $\mathrm{Acu}$ ), and 1 of C. sublineolum (Sub).

\section{$P e l B$ gene amplification and analysis of amplification fragments digestion with restriction enzyme}

The amplification of pelB gene fragments, using the specific primers $\mathrm{P} 1$ and $\mathrm{P} 6$ in 20 isolates of Colletotrichum is illustrated in Figure 6A. There was pelB gene amplification for all isolates of C. gloeosporioides, C. acutatum and C. sublineolum, with amplification products of approximately $600 \mathrm{bp}$, as expected.
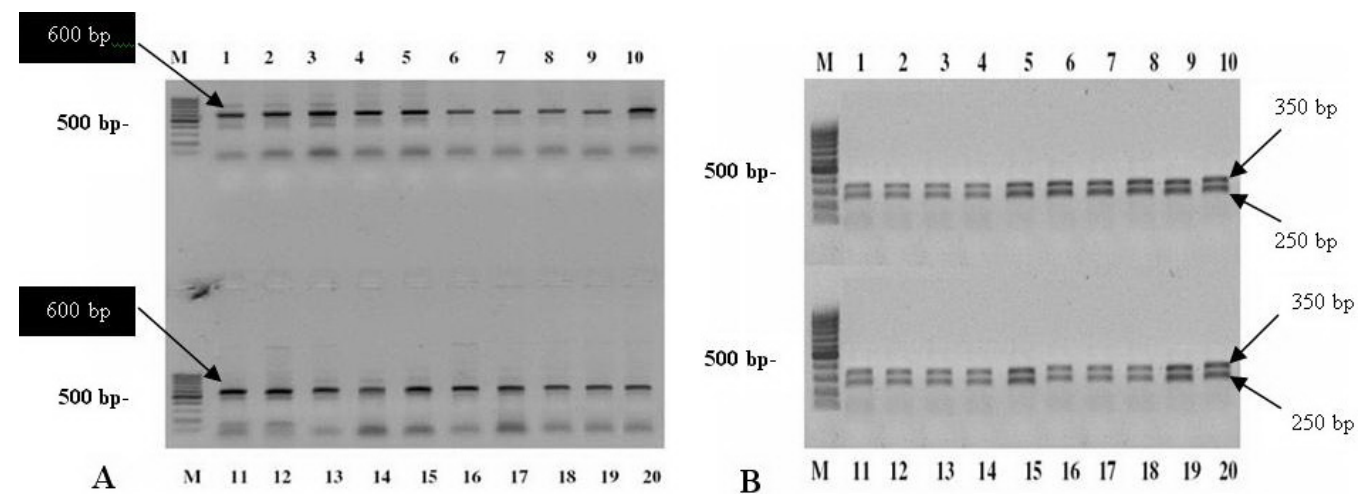

Figure 6. Amplification profiles of the restriction products of the pelB gene with restriction enzyme $M s p I$ (A), amplification of the pelB gene of 20 isolates of the genus Colletotrichum obtained with the primers P1 and P6 (B). Lane $M=$ Molecular weight marker, $100 \mathrm{bp}$. Lanes 1 to $17=$ DNA of Colletotrichum gloeosporioides $(4626,4627$, 4628, 4629, 4894, 4896, 4900, 4905, 4908, 4852, 4854, 4856, 4857, 4858, 4859, Ci, and PI13). Lanes 18 and $19=$ DNA of C. acutatum (PI15 and Acu, respectively). Lane $20=$ DNA of C. sublineolum (Sub). 
The digestion of amplification fragments of the pelB gene of isolates of C. gloeosporioides, C. acutatum and C. sublineolum (Figure 6B) with the enzyme $M s p$ I yielded two fragments of $350 \mathrm{bp}$ and another of $250 \mathrm{bp}$ for all isolates, not showing variation in sequence among the isolates of $C$. gloeosporioides or between the species $C$. acutatum and $C$. sublineolum.

\section{DISCUSSION}

The results show that the use of species-specific primers confirmed the identity of $C$. gloeosporioides isolates stored in the fungal collection-RMU and identified by classical methodology.

The primer CgInt, which is part of the ITS1, designed to identify isolates of C. gloeosporioides, was used with ITS4 by Mills et al. (1992) and Freeman et al. (2000). These studies resulted in the formation of 450-bp fragments for the isolates of $C$. gloeosporioides analyzed, where these results were similar to those found here.

The same specific primers were used by Ureña-Padilla et al. (2002) to confirm the identification of Colletotrichum species from strawberry, which were analyzed to determine the disease etiology. Isolates were identified by PCR using the species-specific primers $\mathrm{Cg}$ / fInt 1 or CaInt2 and ITS4 region of rDNA. All 176 isolates from strawberry were identified as C. gloeosporioides or C. acutatum by amplification of DNA fragment from 450 to $490 \mathrm{bp}$. The primers Cg/fInt1/ITS4 confirmed the identity of 132 isolates of $C$. gloeosporioides obtained from the strawberry crown, and the primers CaInt2/ITS4 confirmed the identity of 46 isolates of $C$. acutatum obtained from fruit rot. Six isolates of $C$. fragariae produced amplification products with the primer $\mathrm{Cg} / \mathrm{fInt} 1 / \mathrm{ITS} 4$.

The primers $(\mathrm{GTG})_{5},(\mathrm{GACA})_{4}$ and $\mathrm{M} 13$ showed the intraspecific variability of isolates from different hosts of $C$. gloeosporioides and also distinguished the isolates of $C$. acutatum and C. sublineolum.

Indeed, the three ISSR primers used showed grouping of isolates of C. gloeosporioides from the same host, with the groups containing onion isolates, mango isolates (except isolate 4852 from the city of Garanhuns using the marker $(\mathrm{GTG})_{5}$ and cashew isolates, all of which originated from different cities in Pernambuco State.

In order to determine host specificity and genetic diversity of different isolates of C. gloeosporioides, Freeman and Shabi (1996) used the ISSR primers (CAG) 5 , (TGTC), $(\mathrm{GACA})_{3}$, and (GACA) $)_{4}$ for genomic DNA amplification of C. gloeosporioides (65 isolates from avocado and 63 from almond) and obtained uniform fragment patterns for all almond isolates from different geographical positions of Israel and also found that almond isolates from the United States were distinct from those from Israel. Avocado isolates from Israel and from the United States were the most diverse. Talhinhas et al. (2005) analyzed isolates from the genus Colletotrichum obtained from olives (Olea europea L.) from Portugal, using the microsatellite primers $(\mathrm{CAC})_{5},(\mathrm{CAG})_{5},(\mathrm{CAG})_{5},(\mathrm{GACG})_{4},(\mathrm{GCA})_{5},(\mathrm{TCC})_{5}$, and $\mathrm{MR}$ and showed intraspecific diversity in C. acutatum and three isolates of C. gloeosporioides from different hosts. Afanador-Kafuri et al. (2003) analyzed 95 species of the genus Colletotrichum isolated from pitomba (Talisia esculenta Radlk.), passion fruit (Passiflora edulis Sims.) and mango (Mangifera indica L.) using the primers $(\mathrm{CAG})_{5},(\mathrm{AGG})_{5},(\mathrm{GACA})_{3}$, and (GACA), and there was indication that the species $C$. acutatum from pitomba showed little genetic variability, while $C$. gloeosporioides isolates from passion fruit and mango were more heterogeneous. Vila Nova (2004) analyzed the genetic variability of 15 isolates of $C$. gloeosporioides 
using RAPD molecular markers and the ITS region of rDNA. In this study, isolates from onion (Allium cepa L.) included 5 from different regions of Pernambuco and 1 from Amazonas, and 9 isolates of the fungus obtained from different hosts. The author found a group of four isolates from onion plants in the dendrogram generated by profiles in the first technique and three of them in the second technique, showing greater homology between isolates from this host. Cavalcante (2005) used the RAPD technique and the ITS1 region of rDNA to analyze the genetic variability of $C$. gloeosporioides isolates, five isolates being from onion and 10 from mango trees of different regions of Pernambuco. In the dendrogram generated by the RAPD analysis, two groups were delineated separating all the mango tree isolates from those obtained in onion. Notably in this study, the isolates from onion and mango in different regions of Pernambuco also formed distinct groups when using the three ISSR primers. Vila Nova (2004) and Cavalcante (2005) using the RAPD technique showed a great genetic diversity among isolates of $C$. gloeosporioides from different hosts of Pernambuco. The results reported here show that clustering based on the host of isolates from different municipalities of Pernambuco State, reinforce the findings of other authors who suggest specialization of the pathogen C. gloeosporioides in relation to the host.

In this study, the presence of the pelB gene was demonstrated in isolates of C. gloeosporioides, C. acutatum and C. sublineolum obtained from the hosts onion, cashew, mango, pepper, peach, cyclamen, and sorghum, and the restriction digestion of the amplified fragment with the enzyme $M s p$ I did not show variation in the gene structure of these three species or between isolates of C. gloeosporioides.

C. gloeosporioides produces endopolygalacturonase (Prusky et al., 1989; Yakoby et al., 2000a), pectin lyase A (Templeton et al., 1994; Bowen et al., 1995), pectin methyl esterase (Ortega, 1996) and pectate lyase B (pelB) (Wattad et al., 1997) during the colonization of infected tissue in avocado. Additionally, it was reported that the species of $C$. gloeosporioides $\mathrm{f}$. sp malvae produce pel-1 and pel-2 (Shih et al., 2000). So far, in the case of C. gloeosporioides, only the pelB gene was found as the true virulence factor, as demonstrated by the reduction in virulence after deletion of the pelB gene (Yakoby et al., 2001) in pathogen isolates of avocado. The $p e l \mathrm{~B}$ genes that encode pectate lyases have also been identified in other species. Lei et al. (1987) identified and characterized a pelB gene from Erwinia carotovora. The pectate lyase B of E. carotovora and E. chrysanthemi consist of 352 and 353 amino acids, respectively. The two proteins show $72 \%$ homology based on data from DNA sequence. Guo et al. (1995) isolated a pelB gene from Fusarium solani f. sp. pisi, which had 65\% homology with pectate lyase A from $F$. solani f. sp. pisi species and no homology with other pectinolytic enzymes.

Studies of this gene were also performed by Prusky et al. (2001) who reported that $C$. gloeosporioides produces pectate lyase, which is a key factor in the development of disease virulence. During the growth of $C$. gloeosporioides, C. acutatum and C. coccodes in acidified medium of yeast extract, the fungus secretes ammonia and thereby increasing the $\mathrm{pH}$. Pectate lyase secretion by C. gloeosporioides increased correspondingly as the $\mathrm{pH}$ in the medium increased. The pelB mutant $C$. gloeosporioides was able to increase ammonia accumulation and $\mathrm{pH}$ in the medium as in the wild type. C. gloeosporioides in avocado, C. coccodes in tomato and C. acutatum in apple (Malus domestica Borkh.) showed ammonia accumulation in the infected area, where the $\mathrm{pH}$ increased to 7.5 or 8 and the pectate lyase activity was optimum. In the nonhost interactions, in which apples were inoculated with C. gloeosporioides, the addition of ammonia compounds significantly enhanced pathogenicity to levels similar to those caused by the 
compatible interaction of $C$. acutatum and apple. The results therefore suggest the importance of ammonia secretion as a virulence factor, increasing the environmental $\mathrm{pH}$ and the pathogenicity of Colletotrichum species. The ability of Colletotrichum species to change $\mathrm{pH}$ at the infection site enhances virulence because ammonia secretion and the resulting increase in $\mathrm{pH}$ leads to a higher expression of pelB and hence a higher pectate lyase secretion (Yakoby et al., 2000b). Prusky et al. (2001) emphasize that the effect of environmental $\mathrm{pH}$ modulation in pectate lyase secretion could be used in programs of selective breeding of plants to control fruit deterioration.

\title{
ACKNOWLEDGMENTS
}

\author{
Research supported by the National Counsel of Technological and Scientific Develop- \\ ment $(\mathrm{CNPq})$ and RENNEBRA.
}

\section{REFERENCES}

Afanador-Kafuri L, Minz D, Maymon M and Freeman S (2003). Characterization of Colletotrichum isolates from tamarillo, passiflora, and mango in Colombia and identification of a unique species from the genus. Phytopathology 93: 579-587.

Bailey JA and Jeger MJ (1992). Colletotrichum: Biology, Pathology and Control. CAB International, Wallingford.

Bayraktar H, Dolar FS and Maden S (2008). Use of RAPD and ISSR markers in detection of genetic variation and population structure among Fusarium oxysporum f. sp. ciceris isolates on chickpea in Turkey. J. Phytopathol. 156: 146-154.

Bowen KJ, Templeton DM, Sharrock RK, Crowhurst NR, et al. (1995). Gene inactivation in the plant pathogen Glomerella cingulata: Three strategies for the disruption of the pectin lyase gene pnlA. Mol. Gen. Genet. 246: 196-205.

Brown AE, Sreenivasaprasad S and Timmer LW (1996). Molecular characterization of slow-growing orange and key lime anthracnose strains of Colletotrichum from citrus as C. acutatum. Phytopathology 86: 523-527.

Bussab WO, Miazaki ES and Andrade DF (1990). Introdução à Análise de Agrupamentos. Associação Brasileira de Estatística, São Paulo.

Cavalcante FCN (2005). Variabilidade de Isolados de Colletotrichum gloeosporioides, quanto a Patogenidade a Frutos de Mangueira (Mangifera indica L.), Marcadores RAPD e Região ITS do rDNA. Master's thesis, Universidade Federal de Pernambuco, Recife.

Chadha S and Gopalakrishna T (2007). Comparative assessment of REMAP and ISSR marker assays for genetic polymorphism studies in Magnaporthe grisea. Curr. Sci. 93: 688-692.

de Barros Lopes M, Soden A, Henschke PA and Langridge P (1996). PCR differentiation of commercial yeast strains using intron splice primers. App. Environ. Microbiol. 62: 4514-4520.

Freeman S and Shabi E (1996). Cross-infection of subtropical and temperate fruits by Colletotrichum species from various hosts. Physiol. Mol. Plant Pathol. 49: 395-404.

Freeman S, Katan T and Shabi E (1998). Characterization of Colletotrichum species responsible for anthracnose diseases of various fruits. Plant Dis. 82: 596-605.

Freeman S, Minz D, Jurkevitch E, Maymon M, et al. (2000). Molecular analyses of Colletotrichum species from almond and other fruits. Phytopathology 90: 608-614.

Guo W, Gonzalez-Candelas L and Kolattukudy PE (1995). Cloning of a novel constitutively expressed pectate lyase gene pelB from Fusarium solani f. sp. pisi (Nectria haematococca, mating type VI) and characterization of the gene product expressed in Pichia pastoris. J. Bacteriol. 177: 7070-7077.

Kuramae-Izioka EE (1997). A rapid easy high yield protocol for a total genomic DNA isolation of Colletotrichum gloeosporioides and Fusarium oxysporum. Rev. UNIMAR 19: 683-689.

Lebeda A, Luhová L, Sedlárová M and Jancova D (2001). The role of enzymes in plant-fungal pathogen interactions. $J$. Plant Dis. Prot. 108: 89-111.

Lei SP, Lin HC, Wang SS, Callaway J, et al. (1987). Characterization of the Erwinia carotovora pelB gene and its product pectate lyase. J. Bacteriol. 169: 4379-4383.

Michereff SJ (2000). Quantificação de Doenças de Plantas. In: Desafio do Manejo Integrado de Pragas e Doenças. Livro de palestras e mini-cursos "Semana de Fitossanidade". Editora Universitária da UFPE, Recife, 63-77. 
Mills PR, Sreenivasaprasad S and Brown AE (1992). Detection and differentiation of Colletotrichum gloeosporioides isolates using PCR. FEMS Microbiol. Lett. 77: 137-143.

Ortega J (1996). Pectolytic enzymes produced by the phytopathogenic fungus Colletotrichum gloeosporioides. Tex. J. Sci. 48: 123-128.

Perfect SE, Hughes HB, O’Connell RJ and Green JR (1999). Colletotrichum: A model genus for studies on pathology and fungal-plant interactions. Fungal Genet. Biol. 27: 186-198.

Prusky D, Gold S and Keen NT (1989). Purification and characterization of an endopolygalacturonase produced by Colletotrichum gloeosporioides. Physiol. Mol. Plant Pathol. 35: 121-133.

Prusky D, McEvoy JL, Leverentz B and Conway WS (2001). Local modulation of host $\mathrm{pH}$ by Colletotrichum species as a mechanism to increase virulence. Mol. Plant Microbe Interact. 14: 1105-1113.

Rohlf FJ (2002). NTSYS-pc. Numerical Taxonomy and Multivariate Analysis System. Version 2.0. Exeter Software, New York.

Rozen S and Skaletsky HJ (2000). Primer3 on the www for General Users and for Biologist Programmers. In: Bioinformatics Methods and Protocols: Methods in Molecular Biology (Krawetz S and Misener S, eds.). Humana Press, Totowa, 365-386. Available at [http://fokker.wi.mit.edu/primer3/]. Accessed Abril 2, 2006.

Sambrook J, Fritsch EF and Maniatis T (1989). Molecular Cloning: a Laboratory Manual. 2nd edn. Cold Spring Harbor Laboratory Press, Cold Spring Harbor.

Shih J, Wei Y and Goodwin PH (2000). A comparison of the pectate lyase genes, pel-1 and pel-2, of Colletotrichum gloeosporioides f. sp. malvae and the relationship between their expression in culture and during necrotrophic infection. Gene 243: 139-150.

Talhinhas P, Sreenivasaprasad S, Neves-Martins J and Oliveira H (2005). Molecular and phenotypic analyses reveal association of diverse Colletotrichum acutatum groups and a low level of C. gloeosporioides with olive anthracnose. Appl. Environ. Microbiol. 71: 2987-2998.

Templeton MD, Sharrock KR, Bowen JK, Crowhurst RN, et al. (1994). The pectin lyase-encoding gene ( $p n l$ ) family from Glomerella cingulata: characterization of pnlA and its expression in yeast. Gene 142: 141-146.

Ureña-Padilla AR, Mackenzie SJ, Bowen BW and Legard DE (2002). Etiology and population genetics of Colletotrichum spp. causing crown and fruit rot of strawberry. Phytopathology 92: 1245-1252.

Vainio EJ, Korhonem K and Hantula J (1998). Genetic variation in Phlebiopsis gigantea as detected with random amplified microsatellite (RAMS) markers. Mycol. Res. 102: 187-192.

Vila Nova MX (2004). Patogenicidade à Cebola (Allium cepa L.) e Análise da Diversidade Genética de Isolados de Colletotrichum gloeosporioides do Estado de Pernambuco, Brasil, por RAPD e Região ITS do rDNA. Master's thesis, Universidade Federal de Pernambuco, Recife.

Wattad C, Kobiler D, Dinoor A and Prusky D (1997). Pectate lyase of Colletotrichum gloeosporioides attacking avocado fruits: cDNA cloning and involvement in pathogenicity. Physiol. Mol. Plant Pathol. 50: 197-212.

Yakoby N, Freeman S, Dinoor A, Keen NT, et al. (2000a). Expression of pectate lyase from Colletotrichum gloeosporioides in C. magna promotes pathogenicity. Mol. Plant Microbe Interact. 13: 887-891.

Yakoby N, Kobiler I, Dinoor A and Prusky D (2000b). pH regulation of pectate lyase secretion modulates the attack of Colletotrichum gloeosporioides on avocado fruits. Appl. Environ. Microbiol. 66: 1026-1030.

Yakoby N, Beno-Moualem D, Keen DT, Dinoor A, et al. (2001). Colletotrichum gloeosporioides pelB is an important virulence factor in avocado fruit-fungus interaction. Mol. Plant Microbe Interact. 14: 988-995.

Yu ZD, Liu XY and Cao ZM (2006). ISSR Marker and ITS Sequence Study of Melampsora Larici-populina. Agric. Sci. China 5: 847-854. 